\section{Kidney \\ Blood Pressure Research}

Review

\title{
Eryptosis - the Neglected Cause of Anemia in End Stage Renal Disease
}

\author{
Florian Lang ${ }^{1,2}$ Rosi Bissinger ${ }^{3} \quad$ Majed Abed $^{1} \quad$ Ferruh Artunc $^{4,5,6}$
}

\begin{abstract}
${ }^{1}$ Department of Physiology I, University of Tübingen, Tübingen, 2Department of Molecular Medicine II, Medical Faculty, Heinrich Heine University, Düsseldorf, ${ }^{3}$ Department of Internal Medicine III, University of Tübingen, Tübingen ${ }^{4}$ Department of Internal Medicine IV, Division of Endocrinology, Diabetology, Vascular Disease, Nephrology and Clinical Chemistry, University Hospital Tübingen, Tübingen, Institute of Diabetes Research and Metabolic Diseases (IDM) of the Helmholtz Center Munich at the University Tübingen, Tübingen, ${ }^{6}$ German Center for Diabetes Research (DZD) at the University Tübingen, Tübingen, Germany
\end{abstract}

\section{Key Words}

Eryptosis • Cell shrinkage • Cell membrane scrambling • End-stage renal disease (ESRD) • Uremic toxins $\cdot$ Microcirculation

\begin{abstract}
End stage renal disease (ESRD) invariably leads to anemia which has been mainly attributed to compromised release of erythropoietin from the defective kidneys with subsequent impairment of erythropoiesis. However, erythropoietin replacement only partially reverses anemia pointing to the involvement of additional mechanisms. As shown more recently, anemia of ESRD is indeed in large part a result of accelerated erythrocyte loss due to suicidal erythrocyte death or eryptosis, characterized by cell shrinkage and cell membrane scrambling with phosphatidylserine translocation to the cell surface. Phosphatidylserine exposing erythrocytes are bound to and engulfed by macrophages and are thus rapidly cleared from circulating blood. If the loss of erythrocytes cannot be fully compensated by enhanced erythropoiesis, stimulation of eryptosis leads to anemia. Eryptotic erythrocytes may further adhere to the vascular wall and thus impair microcirculation. Stimulators of eryptosis include complement, hyperosmotic shock, energy depletion, oxidative stress, and a wide variety of xenobiotics. Signaling involved in the stimulation of eryptosis includes increase of cytosolic $\mathrm{Ca}^{2+}$ activity, ceramide, caspases, calpain, p38 kinase, protein kinase $C$, Janus-activated kinase 3 , casein kinase $1 \alpha$, and cyclin-dependent kinase 4 . Eryptosis is inhibited by AMP-activated kinase, p21-activated kinase 2, cGMP-dependent protein kinase, mitogen- and stress-activated kinase MSK1/2, and some illdefined tyrosine kinases. In ESRD eryptosis is stimulated at least in part by a plasma component, as it is triggered by exposure of erythrocytes from healthy
\end{abstract}




\section{Kidney \\ Blood Pressure Research}

individuals to plasma from ESRD patients. Several eryptosis-stimulating uremic toxins have been identified, such as vanadate, acrolein, methylglyoxal, indoxyl sulfate, indole-3-acetic acid and phosphate. Attempts to fully reverse anemia in ESRD with excessive stimulation of erythropoiesis enhances the number of circulating suicidal erythrocytes and bears the risk of interference with micocirculation, At least in theory, anemia in ESRD could preferably be treated with replacement of erythropoietin and additional inhibition of eryptosis thus avoiding eryptosis-induced impairment of microcirculation. A variety of eryptosis inhibitors have been identified, their efficacy in ESRD remains, however, to be shown.

\section{Introduction}

Mature circulating erythrocytes enjoy an average life span of more than 100 days, which is eventually limited by senescence [1]. Prior to that, erythrocytes may be removed by suicidal death or eryptosis, which is characterized by erythrocyte shrinkage and breakdown of the cell membrane asymmetry with translocation of phosphatidylserine from the cell inside to the cell membrane surface [1-8].

Eryptotic erythrocytes are rapidly cleared from circulating blood [1, 9], as phosphatidylserine exposing erythrocytes bind to respective receptors of phagocytes, are engulfed and are subsequently degraded [1]. As soon as the loss of erythrocytes by stimulated eryptosis surpasses parallel stimulation of erythropoiesis, anemia develops [1].

Phosphatidylserine at the surface of eryptotic erythrocytes further binds to endothelial cells in large part by interaction of phosphatidylserine with the CXC-Motiv-Chemokin 16/ Scavenger receptor (CXCL16/SRPSO) [1]. The adherance of erythrocytes to the vasular wall compromizes microcirculation [1]. Moreover, phosphatidylserine exposing eryptotic erythrocytes bind to blood platelets and may thus trigger blood clotting and thrombosis [1]. Enhanced eryptosis is observed in diverse clinical conditions (see Table 1).

Susceptibility to eryptosis increases with erythrocyte age [39] and the percentage of eryptotic erythrocytes increases following storage of blood [40-71]. Erythrocytes from newborns are highly sensitive to oxidative stress leading to rapid eryptosis and subsequent clearance of those erythrocytes following birth [1].

Eryptosis is triggered by complement, hyperosmotic shock, energy depletion, oxidative stress, cellular $\mathrm{K}^{+}$loss, increase of temperature and a wide variety of xenobiotics $[32,43$, 54, 64, 72-111].

\section{Cellular mechanisms contributing to orchestration of eryptosis}

Eryptosis is triggered by diverse signaling mechanisms [1]. Most importantly, eryptosis is stimulated by a sustained increase of cytosolic $\mathrm{Ca}^{2+}$ activity $\left(\left[\mathrm{Ca}^{2+}\right]_{\mathrm{i}}\right)[1] . \mathrm{Ca}^{2+}$ may enter via $\mathrm{Ca}^{2+}$-permeable unselective cation channels. The channels are activated by

Table 1. Clinical conditions with enhanced eryptosis

\begin{tabular}{l}
\hline Clinical conditions with enhanced eryptosis \\
\hline chronic kidney disease [10-13] \\
diabetes [14, 15] \\
hepatic injury [16] \\
cardiac failure [17] \\
hemolytic uremic syndrome [1,18] \\
dehydration [19] \\
phosphate depletion [1] \\
calcitriol excess [20] \\
inflammation [21] \\
arteritis [22] \\
fever [23] \\
sepsis [24] \\
systemic lupus erythematosus [25] \\
mycoplasma infection [1] \\
malaria [26-28] \\
iron deficiency [29] \\
sickle cell anemia [30] \\
thalassemia [30] \\
glucose 6-phosphate dehydrogenase deficiency [31,32] \\
hereditary spherocytosis [2, 23] \\
paroxysmal nocturnal haemoglobinuria [1] \\
Wilson's disease [1] \\
Parkinson's disease [33] \\
malignancy [2, 34, 35] \\
advanced age [36-38] \\
Newborns [1]
\end{tabular}




\section{Kidney Blood Pressure Research}

prostaglandin $\mathrm{E}_{2}\left(\mathrm{PGE}_{2}\right)[112]$. An increase of $\left[\mathrm{Ca}^{2+}\right]_{\mathrm{i}}$ is followed by activation of $\mathrm{Ca}^{2+}$-sensitive $\mathrm{K}^{+}$channels leading to cell membrane hyperpolarization, $\mathrm{Cl}^{-}$exit, cellular loss of $\mathrm{KCl}$ with osmotically obliged water and thus cell shrinkage [1]. An increase of $\left[\mathrm{Ca}^{2+}\right]_{\mathrm{i}}$ further activates a scramblase leading to cell membrane scrambling with translocation of phosphatidylserine from the inner leaflet of the cell membrane to the erythrocyte surface [1]. The cell membrane scrambling is sensitized for the stimulating effect of $\mathrm{Ca}^{2+}$ by ceramide [6]. Ceramide is generated by a sphingomyelinase which is activated by platelet-activating factor (PAF), a product of phospholipase $A_{2}$ [112].

Stimulation of eryptosis may further involve the heterotrimeric G-protein subunit Gai2 [113]. Several stimulators of eryptosis including oxidative stress, leukotrienes and $\alpha$-lipoic acid are effective through activation of caspases [1, 114]. Eryptosis may be triggered by genetic knockout of adenosine 5'-monophosphate deaminase (AMPD3) [115]. Somewhat surprisingly, regulatory small noncoding RNAs (ncRNAs) contribute to the orchestration of eryptosis [116].

Eryptosis is sensitive to a number of kinases. Eryptosis is stimulated by protein kinase C [1], cyclin-dependent kinase 4 (CDK4) [1, 117], p38 mitogen activated kinase [1], casein kinase $1 \alpha(\mathrm{CK} 1 \alpha)[1]$, and Janus-activated kinase JAK3 [118]. Eryptosis is supressed by the energy sensing AMP-activated kinase (AMPK) [1], p21-activated kinase 2 (PAK2) [1], mitogen- and stress-activated kinase MSK1/2 [119], sorafenib and sunitinib sensitive tyrosine kinases [1], and the cGMP-dependent protein kinase (cGKI). The cGKI is stimulated by nitric oxide (NO), which is accumulated in erythrocytes and is a powerful inhibitor of eryptosis [1].

\section{Enhanced eryptosis in chronic kidney disease}

In end-stage renal disease (ESRD), the reduced renal production and release of erythropoietin (EPO) [120-128] as well as iron deficiency [120,125, 129-132] compromize erythropoiesis, an effect contributing to but not accounting for the development of anemia $[133,134]$.

Compelling evidence suggests that anemia in ESRD results in large part from accelerated clearance of circulating erythrocytes due to stimulation of eryptosis [10-13, 135-140]. In erythropoietin treated patients on dialysis anemia prevails despite enhanced numbers of reticulocytes $[10,136]$. Thus, the anemia is not normalized despite overcompensation of erythropoietin deficiency. The persistance of anema is due to enhanced eryptosis [10, 136]. In ESRD, the percentage of phosphatidylserine-exposing erythrocytes is positively correlated with erythropoietin dosage and the percentage of reticulocytes. The percentage of phosphatidylserine-exposing erythrocytes is significantly higher in patients under hemodialysis than in healthy volunteers $[10,136]$ and even significantly higher in patients on peritoneal dialysis than in healthy volunteers and in patients on hemodialysis [10].

Eryptosis in ESRD is in large part due to a plasma component, as exposure of erythrocytes drawn from healthy individuals to plasma from ESRD patients significantly increases the percentage of phosphatidylserine exposing erythrocytes [10,136]. In patients on hemodialysis, plasma drawn from patients immediately before a dialysis session, but not plasma drawn from patients immediately after a dialysis session stimulates eryptosis [136]. Thus, eryptosis is in large part due to a dialysible plasma component. Despite the removal of eryptosis-inducing plasma components, the percentage of eryptotic erythrocytes is significantly increased immediately after a hemodialysis session, indicating that hemodialysis, in addition to removing eryptosis-stimulating plasma components, per se stimulates eryptosis [136]. In patients on peritoneal dialysis, the percentage of phosphatidylserineexposing erythrocytes was positively correlated with dialysis volume [10].

The plasma components accounting for the stimulation of eryptosis presumably include several uremic toxins (see Table 2). 


\section{Kidney Blood Pressure Research}

Table 2. Eryptosis-inducing Uremic toxins

Eryptosis-inducing Uremic toxins vanadate [141] acrolein [13] methylglyoxal [142] indoxyl sulfate $[12,143]$ indole-3-acetic acid [12] phosphate [144]

Fig. 1. Anemia in ESRD is the result of enhanced eryptosis on the one hand and impaired formation of erythropoietin on the other. Treatment of anemia in ESRD with replacement of erythropoietin alone does ot normalize blood count. Erythropoietin inhibits the unspecific erythrocyte cation channels but cannot prevent accelerated eryptosis in ESRD. Attempts to normalize blood count by administration of excessive erythropoietin jeopardizes microcirculation due to enhanced formation of erythrocytes eventually entering eryptosis and thus adhering to the vascular wall.

The stimulation of eryptosis in ESRD is in part due to increase of $\left[\mathrm{Ca}^{2+}\right]_{\mathrm{i}^{\prime}}$ oxidative stress and ceramide $[10,136]$.

The impact of stimulated eryptosis on anemia in ESRD is similar or even higher than that of erythropoietin deficiency. For instance, the percentage of phosphatidylserine-exposing erythrocytes was twice as high in freshly drawn blood from ESRD patients on peritoneal dialysis as in blood from healthy volunteers [10]. In view of the rapid clearance of phosphatidylserineexposing erythrocytes from circulating blood [1], a doubling of phosphatidylserine-exposing erythrocytes in circulating blood is expected to decrease erythrocyte life span to half. If erythropoiesis would remain constant, the decrease of erythrocyte life span should reduce the number of circulating erythrocytes to half. Thus, severe anemia in ESRD patients can only be prevented by overcompensating erythropoietin deficiency leading to rates of erythropoiesis higher than those in healthy individuals (Figure 1).

In addition to its impact on anemia, eryptosis may interfere with microcirculation, as phosphatidylserine-exposing erythrocytes adhere to the vascular wall [145]. Phosphatidylserine-exposing erythrocytes further stimulate blood clotting [1]. Excessive eryptosis could thus contribute to the known increase of cardiovascular risk in uremic patients $[146,147]$.

In view of the above considerations, attempts to normalize blood count in ESRD patients by stimulation of erythropoiesis increase erythrocyte turnover and thus the number of phosphatidylserine-exposing erythrocytes in circulating blood. Moreover, even though erythropoietin inhibits the $\mathrm{Ca}^{2+}$ permeable cation channel and thus $\mathrm{Ca}^{2+}$ entry [137], the chronic application of erythropoietin leads to the formation of erythrocytes with enhanced susceptibility to eryptosis [148]. Accordingly, the untoward side effects of inadequately high treatment with erythropoietin or other erythropoiesis-stimulating agents [133, 147, 149, $150]$ may at least partially be due to enhanced eryptosis. 


\section{Kidney Blood Pressure Research}

\section{Inhibitors of eryptosis}

In view of the above considerations, treatment of anemia in ESRD should not be restricted to replacement of erythropoietin, but should in addition counteract accelerated eryptosis. As a matter of fact, the stimulation of eryptosis by plasma from uremic patients could be reversed in vitro by addition of L-carnitine [135]. A large number of further substances have previously been shown to inhibit eryptosis (Table 3 ).

Given the complexity of the machinery triggering eryptosis and given the diversity of uremic toxins, many of the above substances may fail to prevent excessive eryptosis in ESRD. In any case, substantial additional experimental effort is needed to uncover the adequate substance or combination of substances for the prevention of premature erythrocyte death in ESRD.

\section{Conclusions}

Similar to apoptosis of nucleated cells, erythrocytes may enter eryptosis, the suicidal erythrocyte death characterized by erythrocyte shrinkage and cell membrane scrambling. Cellular mechanisms orchestrating eryptosis include $\mathrm{Ca}^{2+}$ permeable, $\mathrm{PGE}_{2}$-activated cation channels, ceramide, oxidative stress, caspases, calpain, and several kinases. Enhanced eryptosis is observed in a wide variety of clinical conditions and triggered by a myriad of xenobiotics. Eryptotic cells adhere to endothelial cells, thus interfering with microcirculation, and are rapidly cleared from circulating blood thus causing anemia. Similar to erythropoietin deficiency, excessive eryptosis is a major cause of anemia in ESRD. As treatment of anemia in ESRD by overcompensation of erythropoietin deficiency necessarily leads to increased numbers of circulating suicidal erythrocytes with the respective impairment of microcirculation, a therapeutic approach is needed combining replacement of erythropoietin with inhibition of eryptosis.

\section{Author Disclosure Statement}

No competing financial interests exist.

\section{Acknowledgements}

The authors acknowledge the meticulous preparation of the manuscript by Lejla Subasic. Research in the authors' laboratory was supported by the German Research Foundation (DFG).
Table 3. Inhibitors of eryptosis

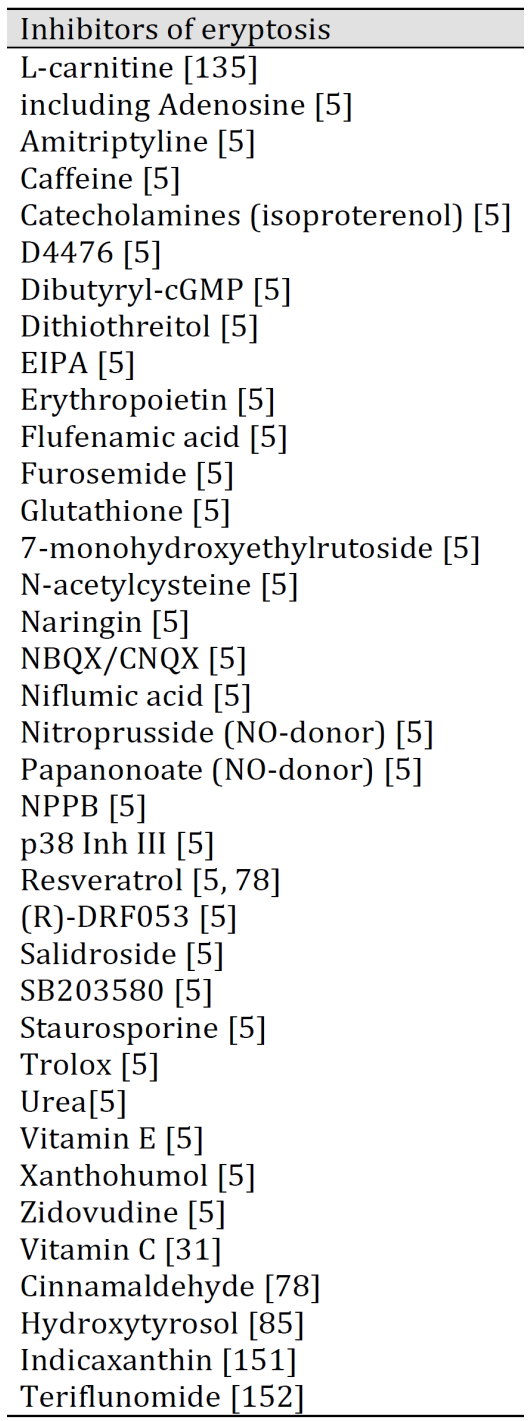




\section{Kidney \\ Blood Pressure Research}

Work of R.B. is supported by the Institutional Strategy of the University of Tübingen (Deutsche Forschungsgemeinschaft, ZUK 63).

\section{References}

1 Lang E, Lang F: Mechanisms and pathophysiological significance of eryptosis, the suicidal erythrocyte death. Semin Cell Dev Biol 2015;39:35-42.

2 Briglia M, Antonia Rossi M, Faggio C: Eryptosis: Ally or Enemy. Curr Med Chem 2016;

-3 Pretorius E, du Plooy JN, Bester J: A Comprehensive Review on Eryptosis. Cell Physiol Biochem 2016;39:1977-2000.

-4 Lang F, Jilani K, Lang E: Therapeutic potential of manipulating suicidal erythrocyte death. Expert Opin Ther Targets 2015;19:1219-1227.

-5 Lang E, Lang F: Triggers, inhibitors, mechanisms, and significance of eryptosis: the suicidal erythrocyte death. Biomed Res Int 2015;2015:513518.

6 Lang E, Bissinger R, Gulbins E, Lang F: Ceramide in the regulation of eryptosis, the suicidal erythrocyte death. Apoptosis 2015;20:758-767.

7 Lang F, Lang KS, Lang PA, Huber SM, Wieder T: Mechanisms and significance of eryptosis. Antioxid Redox Signal 2006;8:1183-1192.

8 Lang F, Qadri SM: Mechanisms and significance of eryptosis, the suicidal death of erythrocytes. Blood Purif 2012;33:125-130.

-9 Larsson A, Hult A, Nilsson A, Olsson M, Oldenborg PA: Red blood cells with elevated cytoplasmic Ca(2+) are primarily taken up by splenic marginal zone macrophages and CD207+ dendritic cells. Transfusion 2016;56:1834-1844.

10 Bissinger R, Artunc F, Qadri SM, Lang F: Reduced Erythrocyte Survival in Uremic Patients Under Hemodialysis or Peritoneal Dialysis. Kidney Blood Press Res 2016;41:966-977.

11 Bonan NB, Steiner TM, Kuntsevich V, Virzi GM, Azevedo M, Nakao LS, Barreto FC, Ronco C, Thijssen S, Kotanko P, Pecoits-Filho R, Moreno-Amaral AN: Uremic Toxicity-Induced Eryptosis and Monocyte Modulation: The Erythrophagocytosis as a Novel Pathway to Renal Anemia. Blood Purif 2016;41:317-323.

12 Gao C, Ji S, Dong W, Qi Y, Song W, Cui D, Shi J: Indolic uremic solutes enhance procoagulant activity of red blood cells through phosphatidylserine exposure and microparticle release. Toxins (Basel) 2015;7:43904403.

13 Ahmed MS, Langer H, Abed M, Voelkl J, Lang F: The uremic toxin acrolein promotes suicidal erythrocyte death. Kidney Blood Press Res 2013;37:158-167.

14 Awasthi S, Gayathiri SK, Ramya R, Duraichelvan R, Dhason A, Saraswathi NT: Advanced Glycation-Modified Human Serum Albumin Evokes Alterations in Membrane and Eryptosis in Erythrocytes. Appl Biochem Biotechnol 2015;177:1013-1024.

15 Viskupicova J, Blaskovic D, Galiniak S, Soszynski M, Bartosz G, Horakova L, Sadowska-Bartosz I: Effect of high glucose concentrations on human erythrocytes in vitro. Redox Biol 2015;5:381-387.

16 Lang E, Pozdeev VI, Gatidis S, Qadri SM, Haussinger D, Kubitz R, Herebian D, Mayatepek E, Lang F, Lang KS, Lang PA: Bile Acid-Induced Suicidal Erythrocyte Death. Cell Physiol Biochem 2016;38:1500-1509.

-17 Attanasio P, Bissinger R, Haverkamp W, Pieske B, Wutzler A, Lang F: Enhanced suicidal erythrocyte death in acute cardiac failure. Eur J Clin Invest 2015;45:1316-1324.

18 Lang PA, Beringer O, Nicolay JP, Amon O, Kempe DS, Hermle T, Attanasio P, Akel A, Schafer R, Friedrich B, Risler T, Baur M, Olbricht CJ, Zimmerhackl LB, Zipfel PF, Wieder T, Lang F: Suicidal death of erythrocytes in recurrent hemolytic uremic syndrome. J Mol Med (Berl) 2006;84:378-388.

19 Abed M, Feger M, Alzoubi K, Pakladok T, Frauenfeld L, Geiger C, Towhid ST, Lang F: Sensitization of erythrocytes to suicidal erythrocyte death following water deprivation. Kidney Blood Press Res 2013;37:567-578.

20 Lang E, Jilani K, Bissinger R, Rexhepaj R, Zelenak C, Lupescu A, Lang F, Qadri SM: Vitamin D-Rich Diet in Mice Modulates Erythrocyte Survival. Kidney Blood Press Res 2015;40:403-412. 


\section{Kidney \\ Blood Pressure Research}

21 Bester J, Pretorius E: Effects of IL-1beta, IL-6 and IL-8 on erythrocytes, platelets and clot viscoelasticity. Sci Rep 2016;6:32188.

-22 Bissinger R, Kempe-Teufel DS, Honisch S, Qadri SM, Randrianarisoa E, Haring HU, Henes J, Lang F: Stimulated Suicidal Erythrocyte Death in Arteritis. Cell Physiol Biochem 2016;39:1068-1077.

-23 Crisp RL, Vota DM, Donato H, Garcia E, Rapetti MC, Maltaneri RE, Vittori DC, Nesse AB: Eryptosis is induced by hyperthermia in hereditary spherocytosis red blood cells. Clin Chem Lab Med 2016;54:e165-168.

-24 Kempe DS, Akel A, Lang PA, Hermle T, Biswas R, Muresanu J, Friedrich B, Dreischer P, Wolz C, Schumacher U, Peschel A, Gotz F, Doring G, Wieder T, Gulbins E, Lang F: Suicidal erythrocyte death in sepsis. J Mol Med (Berl) 2007;85:273-281.

25 Jiang P, Bian M, Ma W, Liu C, Yang P, Zhu B, Xu Y, Zheng M, Qiao J, Shuai Z, Zhou X, Huang D: Eryptosis as an Underlying Mechanism in Systemic Lupus Erythematosus-Related Anemia. Cell Physiol Biochem 2016;40:1391-1400.

-26 Gaudreault V, Wirbel J, Jardim A, Rohrbach P, Scorza T: Red Blood Cells Preconditioned with Hemin Are Less Permissive to Plasmodium Invasion In Vivo and In Vitro. PLoS One 2015;10:e0140805.

-27 Tagami T, Yanai H, Terada Y, Ozeki T: Evaluation of Phosphatidylserine-Specific Peptide-Conjugated Liposomes Using a Model System of Malaria-Infected Erythrocytes. Biol Pharm Bull 2015;38:1649-1651.

28 Jimenez-Diaz MB, Ebert D, Salinas Y, Pradhan A, Lehane AM, Myrand-Lapierre ME, O'Loughlin KG, Shackleford DM, Justino de Almeida M, Carrillo AK, Clark JA, Dennis AS, Diep J, Deng X, Duffy S, Endsley AN, Fedewa G, Guiguemde WA, Gomez MG, Holbrook G, Horst J, Kim CC, Liu J, Lee MC, Matheny A, Martinez MS, Miller G, Rodriguez-Alejandre A, Sanz L, Sigal M, Spillman NJ, Stein PD, Wang Z, Zhu F, Waterson D, Knapp S, Shelat A, Avery VM, Fidock DA, Gamo FJ, Charman SA, Mirsalis JC, Ma H, Ferrer S, Kirk K, Angulo-Barturen I, Kyle DE, DeRisi JL, Floyd DM, Guy RK: (+)-SJ733, a clinical candidate for malaria that acts through ATP4 to induce rapid host-mediated clearance of Plasmodium. Proc Natl Acad Sci U S A 2014;111:E5455-5462.

-29 Pretorius E, Bester J, Kell DB: A Bacterial Component to Alzheimer's-Type Dementia Seen via a Systems Biology Approach that Links Iron Dysregulation and Inflammagen Shedding to Disease. J Alzheimers Dis 2016;53:1237-1256.

30 Chakrabarti A, Halder S, Karmakar S: Erythrocyte and platelet proteomics in hematological disorders. Proteomics Clin Appl 2016;10:403-414.

31 Shan F, Yang R, Ji T, Jiao F: Vitamin C Inhibits Aggravated Eryptosis by Hydrogen Peroxide in Glucose-6Phosphated Dehydrogenase Deficiency. Cell Physiol Biochem 2016;39:1453-1462.

-32 Ghashghaeinia M, Giustarini D, Koralkova P, Koberle M, Alzoubi K, Bissinger R, Hosseinzadeh Z, Dreischer P, Bernhardt I, Lang F, Toulany M, Wieder T, Mojzikova R, Rossi R, Mrowietz U: Pharmacological targeting of glucose-6-phosphate dehydrogenase in human erythrocytes by Bay 11-7082, parthenolide and dimethyl fumarate. Sci Rep 2016;6:28754.

-33 Pretorius E, Swanepoel AC, Buys AV, Vermeulen N, Duim W, Kell DB: Eryptosis as a marker of Parkinson's disease. Aging (Albany NY) 2014;6:788-819.

-34 Bissinger R, Schumacher C, Qadri SM, Honisch S, Malik A, Gotz F, Kopp HG, Lang F: Enhanced eryptosis contributes to anemia in lung cancer patients. Oncotarget 2016;7:14002-14014.

-35 Qadri SM, Mahmud H, Lang E, Gu S, Bobbala D, Zelenak C, Jilani K, Siegfried A, Foller M, Lang F: Enhanced suicidal erythrocyte death in mice carrying a loss-of-function mutation of the adenomatous polyposis coli gene. J Cell Mol Med 2012;16:1085-1093.

-36 Gusev GP, Govekar R, Gadewal N, Agalakova NI: Understanding quasi-apoptosis of the most numerous enucleated components of blood needs detailed molecular autopsy. Ageing Res Rev 2017;35:46-62.

37 Rohrig G: Anemia in the frail, elderly patient. Clin Interv Aging 2016;11:319-326.

-38 Lupescu A, Bissinger R, Goebel T, Salker MS, Alzoubi K, Liu G, Chirigiu L, Mack AF, Qadri SM, Lang F: Enhanced suicidal erythrocyte death contributing to anemia in the elderly. Cell Physiol Biochem 2015;36:773-783.

-39 Wesseling MC, Wagner-Britz L, Huppert H, Hanf B, Hertz L, Nguyen DB, Bernhardt I: Phosphatidylserine Exposure in Human Red Blood Cells Depending on Cell Age. Cell Physiol Biochem 2016;38:1376-1390.

40 Qadri SM, Chen D, Schubert P, Perruzza DL, Bhakta V, Devine DV, Sheffield WP: Pathogen inactivation by riboflavin and ultraviolet light illumination accelerates the red blood cell storage lesion and promotes eryptosis. Transfusion 2016;10.1111/trf.13959 


\section{Kidney \\ Blood Pressure Research}

41 Lang E, Pozdeev VI, Xu HC, Shinde PV, Behnke K, Hamdam JM, Lehnert E, Scharf RE, Lang F, Haussinger D, Lang KS, Lang PA: Storage of Erythrocytes Induces Suicidal Erythrocyte Death. Cell Physiol Biochem 2016;39:668-676.

42 Chang AL, Hoehn RS, Jernigan P, Cox D, Schreiber M, Pritts TA: Previous Cryopreservation Alters the Natural History of the Red Blood Cell Storage Lesion. Shock 2016;46:89-95.

-43 Al Mamun Bhuyan A, Bissinger R, Cao H, Lang F: Triggering of Suicidal Erythrocyte Death by Bexarotene. Cell Physiol Biochem 2016;40:1239-1251.

-44 Al Mamun Bhuyan A, Signoretto E, Bissinger R, Lang F: Stimulation of Suicidal Erythrocyte Death by Ceritinib-Treatment of Human Erythrocytes. Cell Physiol Biochem 2016;40:1129-1140.

45 Aljanadi O, Alzoubi K, Bissinger R, Lang F: Stimulation of Suicidal Erythrocyte Death by Naphthazarin. Basic Clin Pharmacol Toxicol 2015;117:369-374.

46 Almasry M, Jemaa M, Mischitelli M, Faggio C, Lang F: Stimulation of Suicidal Erythrocyte Death by Phosphatase Inhibitor Calyculin A. Cell Physiol Biochem 2016;40:163-171.

47 Alzoubi K, Calabro S, Faggio C, Lang F: Stimulation of suicidal erythrocyte death by sulforaphane. Basic Clin Pharmacol Toxicol 2015;116:229-235.

48 Bissinger R, Bouguerra G, Stockinger K, Abbes S, Lang F: Triggering of Suicidal Erythrocyte Death by Topotecan. Cell Physiol Biochem 2015;37:1607-1618.

-49 Bissinger R, Malik A, Bouguerra G, Zhou Y, Singh Y, Abbes S, Lang F: Triggering of Suicidal Erythrocyte Death by the Antibiotic Ionophore Nigericin. Basic Clin Pharmacol Toxicol 2016;118:381-389.

50 Bouguerra G, Aljanadi O, Bissinger R, Abbes S, Lang F: Embelin-Induced Phosphatidylserine Translocation in the Erythrocyte Cell Membrane. Cell Physiol Biochem 2015;37:1629-1640.

51 Briglia M, Calabro S, Signoretto E, Alzoubi K, Laufer S, Faggio C, Lang F: Fucoxanthin Induced Suicidal Death of Human Erythrocytes. Cell Physiol Biochem 2015;37:2464-2475.

52 Briglia M, Fazio A, Faggio C, Lang F: Triggering of Suicidal Erythrocyte Death by Zosuquidar. Cell Physiol Biochem 2015;37:2355-2365.

53 Briglia M, Fazio A, Faggio C, Laufer S, Alzoubi K, Lang F: Triggering of Suicidal Erythrocyte Death by Ruxolitinib. Cell Physiol Biochem 2015;37:768-778.

54 Calabro S, Alzoubi K, Bissinger R, Faggio C, Lang F: Stimulation of suicidal erythrocyte death by ellipticine. Basic Clin Pharmacol Toxicol 2015;116:485-492.

55 Calabro S, Alzoubi K, Bissinger R, Jilani K, Faggio C, Lang F: Enhanced eryptosis following juglone exposure. Basic Clin Pharmacol Toxicol 2015;116:460-467.

56 Egler J, Lang F: Licochalcone A Induced Suicidal Death of Human Erythrocytes. Cell Physiol Biochem 2015;37:2060-2070.

57 Egler J, Zierle J, Lang F: Stimulating Effect of Manumycin A on Suicidal Erythrocyte Death. Cell Physiol Biochem 2016;38:1147-1156.

-58 Faggio C, Alzoubi K, Calabro S, Lang F: Stimulation of suicidal erythrocyte death by PRIMA-1. Cell Physiol Biochem 2015;35:529-540.

-59 Fazio A, Briglia M, Faggio C, Alzoubi K, Lang F: Oxaliplatin Induced Suicidal Death of Human Erythrocytes. Cell Physiol Biochem 2015;37:2393-2404.

60 Jemaa M, Mischitelli M, Fezai M, Almasry M, Faggio C, Lang F: Stimulation of Suicidal Erythrocyte Death by the CDC25 Inhibitor NSC-95397. Cell Physiol Biochem 2016;40:597-607.

61 Mischitelli M, Jemaa M, Almasry M, Faggio C, Lang F: Triggering of Erythrocyte Cell Membrane Scrambling by Emodin. Cell Physiol Biochem 2016;40:91-103.

62 Mischitelli M, Jemaa M, Almasry M, Faggio C, Lang F: Triggering of Suicidal Erythrocyte Death by Fascaplysin. Cell Physiol Biochem 2016;39:1638-1647.

63 Officioso A, Manna C, Alzoubi K, Lang F: Triggering of Erythrocyte Death by Triparanol. Toxins (Basel) 2015;7:3359-3371.

64 Peter T, Bissinger R, Enkel S, Alzoubi K, Oswald G, Lang F: Programmed erythrocyte death following in vitro Treosulfan treatment. Cell Physiol Biochem 2015;35:1372-1380.

-65 Signoretto E, Bissinger R, Castagna M, Lang F: Stimulation of Eryptosis by Combretastatin A4 Phosphate Disodium (CA4P). Cell Physiol Biochem 2016;38:969-981.

66 Signoretto E, Castagna M, Al Mamun Bhuyan A, Lang F: Stimulating Effect of Terfenadine on Erythrocyte Cell Membrane Scrambling. Cell Physiol Biochem 2016;38:1425-1434. 


\section{Kidney \\ Blood Pressure Research}

Lang et al.: Eryptosis in Chronic Kidney Disease

67 Signoretto E, Castagna M, Lang F: Stimulation of Eryptosis, the Suicidal Erythrocyte Death by Piceatannol. Cell Physiol Biochem 2016;38:2300-2310.

68 Signoretto E, Laufer SA, Lang F: Stimulating Effect of Sclareol on Suicidal Death of Human Erythrocytes. Cell Physiol Biochem 2016;39:554-564.

-69 Waibel S, Bissinger R, Bouguerra G, Abbes S, Lang F: Ritonavir-Induced Suicidal Death of Human Erythrocytes. Basic Clin Pharmacol Toxicol 2016;119:51-57.

70 Zierle J, Bissinger R, Bouguerra G, Abbes S, Lang F: Triggering of Suicidal Erythrocyte Death by Regorafenib. Cell Physiol Biochem 2016;38:160-172.

-71 Zierle J, Bissinger R, Egler J, Lang F: Lapatinib Induced Suicidal Death of Human Erythrocytes. Cell Physiol Biochem 2015;37:2275-2287.

-72 Fezai M, Slaymi C, Ben-Attia M, Lang F, Jemaa M: Purified Lesser weever fish venom (Trachinus vipera) induces eryptosis, apoptosis and cell cycle arrest. Sci Rep 2016;6:39288.

73 Mischitelli M, Jemaa M, Almasry M, Faggio C, Lang F: Stimulation of Erythrocyte Cell Membrane Scrambling by Quinine. Cell Physiol Biochem 2016;40:657-667.

74 Xu D, Ran Q, Xiang Y, Linhai J, Smith BM, Bou-Abdallah F, Lund R, Li Z, Dong H: Toward Hemocompatible Self-assembling Antimicrobial Nanofibers: Understanding the Synergistic Effect of Supramolecular Structure and PEGylation on Hemocompatibility. RSC Adv 2016;6:15911-15919.

75 Peter T, Bissinger R, Lang F: Stimulation of Eryptosis by Caspofungin. Cell Physiol Biochem 2016;39:939949.

76 Al Mamun Bhuyan A, Signoretto E, Bissinger R, Lang F: Enhanced Eryptosis Following Exposure to Dolutegravir. Cell Physiol Biochem 2016;39:639-650.

77 Peter T, Bissinger R, Signoretto E, Mack AF, Lang F: Micafungin-Induced Suicidal Erythrocyte Death. Cell Physiol Biochem 2016;39:584-595.

78 Farag MR, Alagawany M, Tufarelli V: In vitro antioxidant activities of resveratrol, cinnamaldehyde and their synergistic effect against cyadox-induced cytotoxicity in rabbit erythrocytes. Drug Chem Toxicol 2016;10.1080/01480545.2016.11938661-10.

79 Signoretto E, Zierle J, Bhuyan AA, Castagna M, Lang F: Ceranib-2-induced suicidal erythrocyte death. Cell Biochem Funct 2016;34:359-366.

-80 Peter T, Bissinger R, Liu G, Lang F: Anidulafungin-Induced Suicidal Erythrocyte Death. Cell Physiol Biochem 2016;38:2272-2284.

81 Bissinger R, Bhuyan AA, Signoretto E, Lang F: Stimulating Effect of Elvitegravir on Suicidal Erythrocyte Death. Cell Physiol Biochem 2016;38:1111-1120.

82 Signoretto E, Honisch S, Briglia M, Faggio C, Castagna M, Lang F: Nocodazole Induced Suicidal Death of Human Erythrocytes. Cell Physiol Biochem 2016;38:379-392.

83 Macczak A, Cyrkler M, Bukowska B, Michalowicz J: Eryptosis-inducing activity of bisphenol A and its analogs in human red blood cells (in vitro study). J Hazard Mater 2016;307:328-335.

84 Qadri SM, Donkor DA, Bhakta V, Eltringham-Smith LJ, Dwivedi DJ, Moore JC, Pepler L, Ivetic N, Nazi I, FoxRobichaud AE, Liaw PC, Sheffield WP: Phosphatidylserine externalization and procoagulant activation of erythrocytes induced by Pseudomonas aeruginosa virulence factor pyocyanin. J Cell Mol Med 2016;20:710720.

85 Officioso A, Alzoubi K, Lang F, Manna C: Hydroxytyrosol inhibits phosphatidylserine exposure and suicidal death induced by mercury in human erythrocytes: Possible involvement of the glutathione pathway. Food Chem Toxicol 2016;89:47-53.

86 Waibel S, Bissinger R, Bouguerra G, Abbes S, Lang F: Saquinavir Induced Suicidal Death of Human Erythrocytes. Cell Physiol Biochem 2015;37:1973-1982.

-87 Stockinger K, Bissinger R, Bouguerra G, Abbes S, Lang F: Enhanced Eryptosis Following Exposure to Carnosic Acid. Cell Physiol Biochem 2015;37:1779-1791.

-88 Ran Q Xiang Y, Liu Y, Xiang L, Li F, Deng X, Xiao Y, Chen L, Chen L, Li Z: Eryptosis Indices as a Novel Predictive Parameter for Biocompatibility of Fe304 Magnetic Nanoparticles on Erythrocytes. Sci Rep 2015;5:16209.

89 Bouguerra G, Bissinger R, Abbes S, Lang F: Zopolrestat Induced Suicidal Death of Human Erythrocytes. Cell Physiol Biochem 2015;37:1537-1546. 


\section{Kidney \\ Blood Pressure Research}

90 Pagano M, Faggio C: The use of erythrocyte fragility to assess xenobiotic cytotoxicity. Cell Biochem Funct 2015;33:351-355.

91 Officioso A, Alzoubi K, Manna C, Lang F: Clofazimine Induced Suicidal Death of Human Erythrocytes. Cell Physiol Biochem 2015;37:331-341.

$\$ 92$ Velasquez FC, Mate S, Bakas L, Herlax V: Induction of eryptosis by low concentrations of E. coli alphahemolysin. Biochim Biophys Acta 2015;1848:2779-2788.

-93 Peter T, Bissinger R, Lang F: Erythrocyte Shrinkage and Cell Membrane Scrambling after Exposure to the Ionophore Nonactin. Basic Clin Pharmacol Toxicol 2016;118:107-112.

94 Malik A, Bissinger R, Liu G, Liu G, Lang F: Enhanced eryptosis following gramicidin exposure. Toxins (Basel) 2015;7:1396-1410.

-95 Hoque M, Nanduri R, Gupta J, Mahajan S, Gupta P, Saleemuddin M: Oleic acid complex of bovine alphalactalbumin induces eryptosis in human and other erythrocytes by a $\mathrm{Ca}(2+)$-independent mechanism. Biochim Biophys Acta 2015;1850:1729-1739.

-96 Cheung AK, Yang AK, Ngai BH, Yu SS, Gao M, Lau PM, Kong SK: Quantitative detection of eryptosis in human erythrocytes using tunable resistive pulse sensing and annexin-V-beads. Analyst 2015;140:1337-1348.

97 Malik A, Bissinger R, Jilani K, Lang F: Stimulation of erythrocyte cell membrane scrambling by nystatin. Basic Clin Pharmacol Toxicol 2015;116:47-52.

$\$ 98$ Schneider J, Nicolay JP, Foller M, Wieder T, Lang F: Suicidal erythrocyte death following cellular K+ loss. Cell Physiol Biochem 2007;20:35-44.

99 Ghashghaeinia M, Toulany M, Saki M, Bobbala D, Fehrenbacher B, Rupec R, Rodemann HP, Ghoreschi K, Rocken M, Schaller M, Lang F, Wieder T: The NFkB pathway inhibitors Bay 11-7082 and parthenolide induce programmed cell death in anucleated Erythrocytes. Cell Physiol Biochem 2011;27:45-54.

100 Al Mamun Bhuyan A, Bissinger R, Stockinger K, Lang F: Stimulation of Suicidal Erythrocyte Death by Tafenoquine. Cell Physiol Biochem 2016;39:2464-2476.

101 Bissinger R, Waibel S, Lang F: Induction of suicidal erythrocyte death by nelfinavir. Toxins (Basel) 2015;7:1616-1628.

102 Aljanadi O, Alzoubi K, Bissinger R, Lang F: Stimulation of Suicidal Erythrocyte Death by Naphthazarin. Basic Clin Pharmacol Toxicol 2015;117:369-374.

103 Alzoubi K, Egler J, Briglia M, Fazio A, Faggio C, Lang F: Induction of Suicidal Erythrocyte Death by Cantharidin. Toxins (Basel) 2015;7:2822-2834.

104 Bouguerra G, Bissinger R, Abbès S, Lang F: Stimulation of Eryptosis by Narasin. Cell Physiol Biochem 2015;37:1807-1816.

105 Briglia M, Fazio A, Signoretto E, Faggio C, Lang F: Edelfosine Induced Suicidal Death of Human Erythrocytes. Cell Physiol Biochem 2015;37:2221-2230.

106 Calabro S, Alzoubi K, Faggio C, Laufer S, Lang F: Triggering of Suicidal Erythrocyte Death Following Boswellic Acid Exposure. Cell Physiol Biochem 2015;37:131-142.

107 Fazio A, Briglia M, Faggio C, Alzoubi K, Lang F: Stimulation of Suicidal Erythrocyte Death by Garcinol. Cell Physiol Biochem 2015;37:805-815.

108 Mischitelli M, Jemaà M, Almasry M, Faggio C, Lang F: Ca2+ Entry, Oxidative Stress, Ceramide and Suicidal Erythrocyte Death Following Diosgenin Treatment. Cell Physiol Biochem 2016;39:1626-1637.

109 Mischitelli M, Jemaà M, Almasry M, Faggio C, Lang F: Stimulation of Suicidal Erythrocyte Death by Rottlerin. Cell Physiol Biochem 2016;40:558-566.

110 Signoretto E, Zierle J, Bissinger R, Castagna M, Bossi E, Lang F: Triggering of Suicidal Erythrocyte Death by Pazopanib. Cell Physiol Biochem 2016;38:926-938.

111 Bissinger R, Waibel S, Bouguerra G, Al Mamun Bhuyan A, Abbès S, Lang F: Enhanced Eryptosis Following Exposure to Lopinavir. Cell Physiol Biochem 2015;37:2486-2495.

112 Lang PA, Kempe DS, Tanneur V, Eisele K, Klarl BA, Myssina S, Jendrossek V, Ishii S, Shimizu T, Waidmann M, Hessler G, Huber SM, Lang F, Wieder T: Stimulation of erythrocyte ceramide formation by plateletactivating factor. J Cell Sci 2005;118:1233-1243.

113 Bissinger R, Lang E, Ghashghaeinia M, Singh Y, Zelenak C, Fehrenbacher B, Honisch S, Chen H, Fakhri H, Umbach AT, Liu G, Rexhepaj R, Liu G, Schaller M, Mack AF, Lupescu A, Birnbaumer L, Lang F, Qadri SM: Blunted apoptosis of erythrocytes in mice deficient in the heterotrimeric G-protein subunit Galphai2. Sci Rep 2016;6:30925. 


\section{Kidney \\ Blood Pressure Research}

Lang et al.: Eryptosis in Chronic Kidney Disease

114 Bhavsar SK, Bobbala D, Xuan NT, Foller M, Lang F: Stimulation of suicidal erythrocyte death by alpha-lipoic acid. Cell Physiol Biochem 2010;26:859-868.

115 Hortle E, Nijagal B, Bauer DC, Jensen LM, Ahn SB, Cockburn IA, Lampkin S, Tull D, McConville MJ, McMorran BJ, Foote SJ, Burgio G: Adenosine monophosphate deaminase 3 activation shortens erythrocyte half-life and provides malaria resistance in mice. Blood 2016;128:1290-1301.

116 Sarachana T, Kulkarni S, Atreya CD: Evaluation of small noncoding RNAs in ex vivo stored human mature red blood cells: changes in noncoding RNA levels correlate with storage lesion events. Transfusion 2015;55:2672-2683.

-117 Lang E, Zelenak C, Eberhard M, Bissinger R, Rotte A, Ghashghaeinia M, Lupescu A, Lang F, Qadri SM: Impact of cyclin-dependent kinase CDK4 inhibition on eryptosis. Cell Physiol Biochem 2015;37:1178-1186.

118 Bhavsar SK, Gu S, Bobbala D, Lang F: Janus kinase 3 is expressed in erythrocytes, phosphorylated upon energy depletion and involved in the regulation of suicidal erythrocyte death. Cell Physiol Biochem 2011;27:547-556.

119 Lang E, Bissinger R, Fajol A, Salker MS, Singh Y, Zelenak C, Ghashghaeinia M, Gu S, Jilani K, Lupescu A, Reyskens KM, Ackermann TF, Foller M, Schleicher E, Sheffield WP, Arthur JS, Lang F, Qadri SM: Accelerated apoptotic death and in vivo turnover of erythrocytes in mice lacking functional mitogen- and stressactivated kinase MSK1/2. Sci Rep 2015;5:17316.

120 Adamson JW: Hyporesponsiveness to erythropoiesis stimulating agents in chronic kidney disease: the many faces of inflammation. Adv Chronic Kidney Dis 2009;16:76-82.

121 Artunc F, Risler T: Serum erythropoietin concentrations and responses to anaemia in patients with or without chronic kidney disease. Nephrol Dial Transplant 2007;22:2900-2908.

-122 Atkinson MA, Furth SL: Anemia in children with chronic kidney disease. Nat Rev Nephrol 2011;7:635-641.

123 Besarab A, Frinak S, Yee J: What is so bad about a hemoglobin level of 12 to $13 \mathrm{~g} / \mathrm{dL}$ for chronic kidney disease patients anyway? Adv Chronic Kidney Dis 2009;16:131-142.

124 Fishbane S, Nissenson AR: Anemia management in chronic kidney disease. Kidney Int Suppl 2010;10.1038/ki.2010.188S3-9.

125 Macdougall IC, Ashenden M: Current and upcoming erythropoiesis-stimulating agents, iron products, and other novel anemia medications. Adv Chronic Kidney Dis 2009;16:117-130.

126 Parfrey PS: Critical appraisal of randomized controlled trials of anemia correction in patients with renal failure. Curr Opin Nephrol Hypertens 2011;20:177-181.

127 Wish JB: Past, present, and future of chronic kidney disease anemia management in the United States. Adv Chronic Kidney Dis 2009;16:101-108.

128 Yee J, Zasuwa G, Frinak S, Besarab A: Hemoglobin variability and hyporesponsiveness: much ado about something or nothing? Adv Chronic Kidney Dis 2009;16:83-93.

129 Attanasio P, Ronco C, Anker SD, Cicoira M, von Haehling S: Role of iron deficiency and anemia in cardiorenal syndromes. Semin Nephrol 2012;32:57-62.

130 Besarab A, Coyne DW: Iron supplementation to treat anemia in patients with chronic kidney disease. Nat Rev Nephrol 2010;6:699-710.

131 Kovesdy CP: Iron and clinical outcomes in dialysis and non-dialysis-dependent chronic kidney disease patients. Adv Chronic Kidney Dis 2009;16:109-116.

132 Kwack C, Balakrishnan VS: Managing erythropoietin hyporesponsiveness. Semin Dial 2006;19:146-151.

133 Dmitrieva O, de Lusignan S, Macdougall IC, Gallagher H, Tomson C, Harris K, Desombre T, Goldsmith D: Association of anaemia in primary care patients with chronic kidney disease: cross sectional study of quality improvement in chronic kidney disease (QICKD) trial data. BMC Nephrol 2013;14:24.

134 Yang M, Fox CH, Vassalotti J, Choi M: Complications of progression of CKD. Adv Chronic Kidney Dis 2011;18:400-405.

135 Sun Y, Liu G, Li X, Shi Y, Guan G: L-Carnitine inhibits eryptosis induced by uremic serum and the related mechanisms. Ren Fail 2015;37:1050-1056.

136 Abed M, Artunc F, Alzoubi K, Honisch S, Baumann D, Foller M, Lang F: Suicidal erythrocyte death in endstage renal disease. J Mol Med (Berl) 2014;92:871-879.

137 Myssina S, Huber SM, Birka C, Lang PA, Lang KS, Friedrich B, Risler T, Wieder T, Lang F: Inhibition of erythrocyte cation channels by erythropoietin. J Am Soc Nephrol 2003;14:2750-2757. 


\section{Kidney \\ Blood Pressure Research}

Lang et al.: Eryptosis in Chronic Kidney Disease

138 Polak-Jonkisz D, Purzyc L: Ca(2+) influx versus efflux during eryptosis in uremic erythrocytes. Blood Purif 2012;34:209-210; author reply 210.

139 Popolo A, Autore G, Pinto A, Marzocco S: Oxidative stress in patients with cardiovascular disease and chronic renal failure. Free Radic Res 2013;47:346-356.

140 Vos FE, Schollum JB, Coulter CV, Doyle TC, Duffull SB, Walker RJ: Red blood cell survival in long-term dialysis patients. Am J Kidney Dis 2011;58:591-598.

-141 Foller M, Sopjani M, Mahmud H, Lang F: Vanadate-induced suicidal erythrocyte death. Kidney Blood Press Res 2008;31:87-93.

142 Nicolay JP, Schneider J, Niemoeller OM, Artunc F, Portero-Otin M, Haik G, Jr., Thornalley PJ, Schleicher E, Wieder T, Lang F: Stimulation of suicidal erythrocyte death by methylglyoxal. Cell Physiol Biochem 2006;18:223-232.

143 Ahmed MS, Abed M, Voelkl J, Lang F: Triggering of suicidal erythrocyte death by uremic toxin indoxyl sulfate. BMC Nephrol 2013;14:244.

144 Voelkl J, Alzoubi K, Mamar AK, Ahmed MS, Abed M, Lang F: Stimulation of suicidal erythrocyte death by increased extracellular phosphate concentrations. Kidney Blood Press Res 2013;38:42-51.

145 Borst O, Abed M, Alesutan I, Towhid ST, Qadri SM, Foller M, Gawaz M, Lang F: Dynamic adhesion of eryptotic erythrocytes to endothelial cells via CXCL16/SR-PSOX. Am J Physiol Cell Physiol 2012;302:C644651.

146 Palmer SC, Navaneethan SD, Craig JC, Johnson DW, Tonelli M, Garg AX, Pellegrini F, Ravani P, Jardine M, Perkovic V, Graziano G, McGee R, Nicolucci A, Tognoni G, Strippoli GF: Meta-analysis: erythropoiesisstimulating agents in patients with chronic kidney disease. Ann Intern Med 2010;153:23-33.

147 Staude H, Jeske S, Schmitz K, Warncke G, Fischer DC: Cardiovascular risk and mineral bone disorder in patients with chronic kidney disease. Kidney Blood Press Res 2013;37:68-83.

148 Foller M, Kasinathan RS, Koka S, Huber SM, Schuler B, Vogel J, Gassmann M, Lang F: Enhanced susceptibility to suicidal death of erythrocytes from transgenic mice overexpressing erythropoietin. Am J Physiol Regul Integr Comp Physiol 2007;293:R1127-1134.

149 Elliott J, Mishler D, Agarwal R: Hyporesponsiveness to erythropoietin: causes and management. Adv Chronic Kidney Dis 2009;16:94-100.

150 Singh AK: What is causing the mortality in treating the anemia of chronic kidney disease: erythropoietin dose or hemoglobin level? Curr Opin Nephrol Hypertens 2010;19:420-424.

151 Tesoriere L, Attanzio A, Allegra M, Livrea MA: Dietary indicaxanthin from cactus pear (Opuntia ficus-indica L. Mill) fruit prevents eryptosis induced by oxysterols in a hypercholesterolaemia-relevant proportion and adhesion of human erythrocytes to endothelial cell layers. Br J Nutr 2015;114:368-375.

152 Zierle J, Bissinger R, Lang F: Inhibition by Teriflunomide of Erythrocyte Cell Membrane Scrambling Following Energy Depletion, Oxidative Stress and Ionomycin. Cell Physiol Biochem 2016;39:1877-1890. 